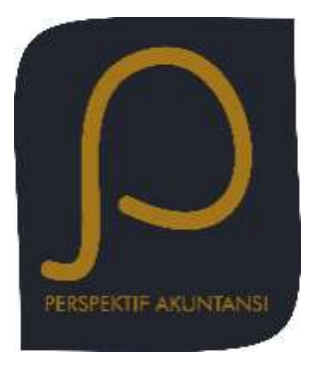

Perspektif Akuntansi

Volume 2 Nomor 1 (Februari 2019), hal. 89-108

ISSN: 2623-0194(Print), 2623-0186(Online)

Copyright(C) The Authors(s). All Rights Reserved

Fakultas Ekonomika dan Bisnis,

Universitas Kristen Satya Wacana

DOI: https://doi.org/10.24246/persi.v2i1.p89-108

http://ejournal.uksw.edu/persi

\title{
Sistem Akuntansi Manajemen Memediasi Gaya Kepemimpinan dan Desentralisasi Terhadap Kinerja Manajerial
}

Putri Fea Ikhtiyarini

Fakultas Ekonomi dan Bisnis, Universitas Dian Nuswantoro

Zaky Machmuddah ${ }^{1}$

Fakultas Ekonomi dan Bisnis, Universitas Dian Nuswantoro

Received Abstract. The aim of the research was to examine whether the 30/10/2018 management accounting system mediated the effect of leadership styles and decentralization on managerial performance. The object of the Accepted study was PT. Perkebunan Nusantara IX Balong located in Jepara, 12/12/2018 Central Java, Indonesia. This study used WarpPLS method. Data were obtained by distributing questionnaires to 101 middle managers of PT. Perkebunan Nusantara IX Balong. The results of the research showed that leadership style had no effect on managerial performance, decentralization had no effect on managerial performance, management accounting system mediated the effect of leadership styles on managerial performances, and management accounting system mediated the effect of decentralization on managerial performance.

Keywords: management accounting systems, leadership styles, decentralization, managerial performance

Abstrak. Mengetahui apakah Sistem Akuntansi Manajemen (SAM) memediasi pengaruh gaya kepemimpinan dan desentralisasi terhadap kinerja manajerial merupakan tujuan utama dari penelitian ini. Obyek penelitian ini adalah PT. Perkebunan Nusantara IX Balong Jepara (Persero) yang berlokasi di Jepara, Jawa Tengah, Indonesia. Metode Warp PLS digunakan sebagai alat untuk mengolah data dalam penelitian ini. Data diperoleh dengan menyebarkan kuesioner

${ }^{1}$ zaky.machmuddah@dsn.dinus.ac.id 
terhadap 101 manajer menengah pada PT. Perkebunan Nusantara IX Balong Jepara (Persero). Hasil penelitian membuktikan bahwa gaya kepemimpinan tidak berpengaruh terhadap kinerja manajerial, desentralisasi tidak berpengaruh terhadap kinerja manajerial, gaya kepemimpinan yang dimediasi oleh sistem akuntansi manajemen berpengaruh signifikan terhadap kinerja manajerial dan desentralisasi yang dimediasi oleh sistem akuntansi manajemen berpengaruh signifikan terhadap kinerja manajerial.

Kata kunci: sistem akuntansi manajemen; gaya kepemimpinan, desentralisasi, kinerja manajerial

\section{Pendahuluan}

Salah satu faktor paling penting di suatu perusahaan khususnya dalam organisasi yaitu kinerja manajerial, karena semakin meningkatnya kinerja manajerial akan semakin meningkatnya pula kinerja organisasi secara keseluruhan (Namawi, 2005). Suatu organisasi bisa berhasil karena adanya manusia sebagai faktor keberhasilannya. Sumber daya manusia (SDM) yang potensial selalu diinginkan oleh setiap perusahaan, SDM berfungsi sebagai penentu agar bisa mencapai tujuan di dalam suatu perusahaan. Yang dimaksud dengan SDM di sini adalah karyawan maupun pemimpin pada pola tugas dan pengawasan (Namawi, 2005).

Fenomena yang terjadi pada PT. Perkebunan Nusantara IX Balong Jepara adalah pengelolaan kinerja manajerial yang masih lemah. Hal ini ditunjukan dari produktivitas yang tercatat di PT. Perkebunan Nusantara IX Balong Jepara (Persero) mengalami penurunan. Data hasil produksi PT. Perkebunan Nusantara IX Balong Jepara (Persero) pada tahun 2013 menunjukkan tingkat produksi mencapai 103.2\%, namun demikian pada tahun 2014 hasil produksi yang dicapai hanya sebesar 91.9\%. Data tersebut menunjukkan bahwa catatan produktivitas PT. Perkebunan Nusantara IX Balong Jepara (Persero) mengalami penurunan sebesar $11.3 \%$.

Kondisi di atas menunjukkan adanya masalah yang berhubungan dengan kinerja manajerial. Sistem akuntansi manajemen (SAM) menentukan peningkatan kinerja manajerial, para manajer diberi informasi yang relevan dan handal dari SAM, hal tersebut merupakan peran utama dari SAM. Khususnya SAM dinilai sebagai subsistem dalam pengendalian organisasi (Lempas et al., 2014).

Peran dari SAM yaitu mampu memprediksi akibat yang akan terjadi atas macam-macam pilihan perbuatan yang bisa dilakukan untuk semua kegiatan seperti penjadwalan, pengamatan, dan pengutipan suatu keputusan. Oleh karenanya dibutuhkan suatu sistem yang bisa menyediakan keperluan informasi, baik informasi akuntansi ataupun informasi manajemen untuk 
mengambil suatu keputusan yang baik. Bagi perusahaan informasi yang baik yaitu informasi yang mempunyai karakteristik bersifat broadsocpe, timelines, aggregrate, dan integrated.

Yuliana (2010) menyatakan jika SAM mempunyai kedudukan yang sangat penting sebagai variabel intervening antara ikatan gaya kepemimpinan dengan kinerja organisasi. Perolehan dari analisis yang membuktikan kedudukan SAM sebagai pemediasi pengaruh desentralisasi kepada kinerja manajerial dilakukan oleh Lempas et al. (2014). Selain itu Lempas et al. (2014) juga membuktikan bahwa dalam tahap desentralisasi tinggi diperlukan karakter informasi SAM yang semakin relevan supaya makin tinggi pengaruh positif ke kinerja manajerial.

Desentralisasi memberikan bantuan kepada peningkatan kinerja manajerial, seperti yang diungkapkan Cahyadi \& Handoko (2010). Tingkat desentralisasi yang tinggi merupakan cara benar untuk menanggapi peningkatan ketidakpastian, jadi dapat membantu penerimaan kinerja manajerial yang lebih baik lagi (Cahyadi \& Handoko, 2010). Sistem desentralisasi, manajer puncak mendelegasikan wewenang beserta tanggung jawabnya terhadap manajer yang lebih rendah dengan kewenangan khusus, hal tersebut sejalan dengan Cahyaningrum \& Suprapti (2016).

Desentralisasi diarahkan untuk peningkatan kinerja manajerial dengan cara mendorong manajer untuk membangun kemampuannya dengan cara memerankan gaya kepemimpinan dengan baik. Gaya kepemimpinan yang diperankan dengan baik akan membuat suatu organisasi di dalam perusahaan menjadi lebih baik pula, seperti pemimpin yang selalu memberikan motivasi kepada karyawan.

Dampak perilaku pemimpin pada motivasi bawahan telah dijelaskan oleh teori path-goal. Robbins \& Coulter (2010) mengatakan jika isi dari path goal theory yaitu kewajiban pemimpin untuk menyampaikan pemberitahuan dan bantuan yang diperlukan terhadap semua anggota agar bisa mencapai suatu tujuan. Istilah path goal bermula dari keyakinan bahwa para pemimpin yang membawakan hasil semestinya bisa menunjukan arah yang berfungsi untuk membantu anggotanya memperoleh suatu hal yang dibutuhkan demi tercapainya arah kerja dan meringankan perjalanan serta menghapuskan semua rintangan yang ada.

Penelitian yang dilakukan oleh Ogbonna \& Harris (2000) tentang hubungan antara kepemimpinan dengan kinerja, menyatakan bahwa kepemimpinan yang berperan sangat baik dari seorang pemimpin bisa memberikan motivasi karyawan untuk bekerja semaksimal mungkin, sehingga akan membentuk karyawan lebih berhati-hati lagi untuk pencapaian tujuan yang diinginkan oleh 
perusahaan, hal tersebut berpengaruh pada kinerjanya. Elenkov (2002) menyatakan bahwa kepemimpinan berpengaruh positif secara langsung terhadap kinerja. Hasil penelitian dari Rowold (2011); Rante et al. (2014); dan Tucunan et al. (2014) menyimpulkan hal yang sama bahwa kepemimpinan berpengaruh signifikan terhadap kinerja dan mengkaji perihal yang berdampak pada kepemimpinan terhadap kondisi kinerja dan kinerja organisasi non profit. Namun demikian, hasil penelitian Suryo (2008); Nurwati et al. (2012); serta Widhi \& Setyawati (2015) menemukan bukti bahwa gaya kepemimpinan tidak mempunyai pengaruh yang signifikan terhadap kinerja.

Bervariasinya hasil temuan penelitian sebelumnya dijadikan alasan mengapa hal ini perlu dikaji ulang. Kebaruan dari penelitian ini adalah memasukkan peran dari sistem akuntansi manajemen untuk memediasi gaya kepemimpinan dan desentralisasi untuk meningkatkan kinerja manajerial. Oleh karena itu, dalam artikel ini akan membahas mengenai variabel-variabel terkait. Gaya kepemimpinan dan desentralisasi ditetapkan sebagai variabel konteks dan seperti apa pengaruh secara langsung pada kinerja manajerial, serta pengaruh tidak langsung pada kinerja manajerial melalui SAM.

Pertanyaan yang harus dijawab dalam penelian ini adalah: (1) apakah gaya kepemimpinan berpengaruh terhadap kinerja manajerial? (2) apakah desentralisasi berpengaruh terhadap kinerja manajerial? (3) apakah gaya kepemimpinan berpengaruhterhadap kinerja manajerial apabila dimediasi oleh SAM? (4) apakah desentralisasi berpengaruhterhadap kinerja manajerial apabila dimediasi oleh SAM? Dengan demikian tujuan dari penelitian ini adalah menguji secara empiris peranan SAM dalam memediasi pengaruh gaya kepemimpinan dan desentralisasi terhadap kinerja manajerial baik secara langsung ataupun secara tidak langsung.

\section{Telaah Pustaka}

\section{Teori Kontijensi}

Pendekatan kontijensi pada sistem akuntansi manajemen berdasarkan pada premis umum bahwa tidak ada sistem akuntansi manajemen secara universal yang selalu tepat untuk dapat diterapkan pada seluruh organisasi dalam setiap keadaan akan tetapi sistem akuntansi manajemen (SAM) bergantung pada faktor-faktor situasional dalam organisasi (Otley, 1980). Teori Kontijensi mengungkapkan bahwa seluruh elemen dari suatu organisasi harus memiliki kecocokan atau kesamaan (fit) antara satu dengan yang lainnya. Simons (1987) mengidentifikasi hubungan ini menjadi suatu persyaratan untuk menumbuhkan teoretis desain sistem akuntansi manajemen. Pendekatan kontijensi banyak diminati peneliti karena mereka ingin mengerti apakah 
tingkat keandalan sistem akuntansi manajemen akan terus berpengaruh terhadap kinerja pada setiap keadaan atau tidak. Berdasarkan pada tingkat kontijensi tersebut, ada dua asumsi bahwa adanya aspek kontekstual yang saling berinteraksi sepadan dengan keadaan khusus yang dihadapi.

Organisasi dan manajerial menyatakan bahwa organisasi adalah bentuk yang terdiri atas beberapa subsistem antara organisasi dengan lingkungan dan berusaha untuk mengetahui bagaimana organisasi beroprasi di dalam berbagai keadaan maupun dalam keadaan tertentu sehingga bisa diarahkan untuk mencapai berbagai persiapanorganisasi yang diinginkan dan tanggapan manajemen yang tepat pada suatu keadaan tertentu dan menegaskan bentuk variabel, yang menempatkan bermacam-macam sifat organisasi (Chong \& Chong, 1997).

Para peneliti banyak yang berminat untuk meneliti apakah kualitas keunggulan sistem akuntansi manajemen berpengaruh berbeda ataukah sama dengan setiap organisasi. Berdasar pada pendekatan kontijensi tersebut maka ada kemungkinan terdapat variabel penentu lainnya yang akan saling berkomunikasi, sepadan dengan kondisi yang sedang dihadapi. Informasi manajemen dalam penelitian ini yaitu informasi yang memiliki karakteristik broad scope, integration, timeliness, aggregation.

\section{Pengembangan Hipotesis}

Pola perilaku yang dimiliki oleh pemimpin selama proses mengarahkan atau membimbing serta mempengaruhi para pekerja disebut dengan gaya kepemimpinan. Gaya kepemimpinan dalam perusahaan sebagai faktor yang dominan dalam menentukan dan pembentukan karakter perusahaan. Selanjutnya karakter perusahaan akan mempengaruhi output dari kinerja manajerial. Gaya kepemimpinan seorang manajer dalam perusahaan akan berpengaruh terhadap kinerja dari masing-masing anggota organisasi. Gaya kepemimpinan dapat mempengaruhi kreatifitas kinerja manajer dalam melaksanakan tugasnya sebagai anggota organisasi. Teori kontijensi menyatakan bahwa kelompok efektif tergantung pada kecocokan antara gaya pemimpin yang berinteraksi dengan subordinatnya, sehingga situasi menjadi pengendali dan berpengaruh terhadap pemimpin. Para pemimpin mencoba melakukan pengaruhnya kepada anggota kelompok dalam kaitannya dengan situasi-situasi yang spesifik. Dengan demikian, jika pemimpin bisa menyemangati karyawannya agar bekerja semaksimal mungkin, maka karyawan akan berusaha untuk mencapai target dan bekerja lebih hati-hati yang memberikan dampak pada pencapaian kinerja (Rante et al., 2014).

Argumentasi di atas sesuai dengan hasil penelitian yang dikemukakan oleh Yuliana (2010); Rante et al. (2014); Tucunan et al. (2014). Berdasarkan 
argumentasi dan penelitian yang mendukung maka hipotesis penelitian ini dinyatakan sebagai berikut:

$\mathbf{H}_{\mathbf{1}}$ : Gaya kepemimpinan berpengaruh terhadap kinerja manajerial.

Peningkatan kompleksitas administrasi, tugas dan tanggung jawab, sebaiknya sebagian tugas-tugas didelegasikan ke tingkat manajemen yang lebih rendah untuk meringankan beban pengambilan keputusan di tingkat manajemen yang lebih tinggi (Gordon \& Miller, 1976). Pernyataan tersebut sesuai dengan hasil dari analisis statistika inferensial terdapat bukti bahwa desentralisasi berpengaruh signifikan terhadap kinerja manajerial, yang berarti semakin tinggi tingkatan delegasi wewenang dan pertanggungjawaban manajemen atas pada manajer menengah dan bawah untuk pembuatan suatukeputusan maka semakin tinggi pula tingkat kinerja manajerial. Hal ini sesuai dengan teori kontijensi yang menyatakan bahwa kebebasan dan pendelegasian tugas serta wewenang yang luas kepada bawahan, sehingga pemimpin hanya memberikan pengarahan dan pengawasan, karena bawahan mempunyai kemampuan yang tinggi dalam menyelesaikan tugasnya dengan efektif dan efisien.

Sari (2016); Cahyaningrum \& Suprapti (2016); Lempas et al. (2014); Rante et al. (2014); dan Nurwati et al. (2012), menyatakan bahwa desentralisasi akan membuat para manajer secara baik menangani semua peristiwa yang ada, dan selalu berkerja tanpa menunggu perintah dan mendorong agar kinerjanya bisa lebih maksimal lagi. Penjelasan dan hasil penelitian pendukung di atas memperkuat hipotesis yang dirumuskan dalam penelitian ini, yaitu:

$\mathbf{H}_{2}$ : Desentralisasi berpengaruh terhadap kinerja manajerial.

Gaya kepemimpinan berpengaruh secara signifikan terhadap SAM begitu juga, SAM berpengaruh secara signifikan terhadap kinerja manajerial. SAM dapat membantu para manajer mengidentifiksasi suatu masalah, menyelesaikan masalah, dan mengevaluasi kinerja untuk meningkatkan kinerja manajerial. SAM dengan kebutuhan pembuat keputusan dapat meningkatkan kualitas keputusan yang akan diambil dan akan meningkatkan gaya kepemimpinan seorang manajer. Manajer sangat berkepentingan dengan informasi benchmarking dan pengendalian yang tersedia dalam SAM untuk mencapai hasil yang diharapkan dan mempunyai nilai tambah dibanding pesaing. Hal ini sesuai dengan teori kontijensi yang menyatakan bahwa SAM dan gaya kepemimpinan merupakan faktor kondisional yang akan mengalami penyesuaian sehubungan dengan kondisi situasional yang terjadi dalam perusahaan yang menyebabkan perbedaan kebutuhan informasi (Rante et al., 2014).

Rante et al. (2014) dan Yuliana (2010) membuktikan secara empiris bahwa gaya kepemimpinan dengan lingkup SAM yang baik berpengaruh positif pada 
kinerja manajerial. Atas dasar logika dan kajian teori kontijensi, maka hipotesis penelitian ini adalah:

$\mathbf{H}_{3}$ : SAM memediasi pengaruh gaya kepemimpinan terhadap kinerja manajerial.

Desentralisasi berpengaruh secara signifikan terhadap SAM begitu juga, SAM berpengaruh secara signifikan terhadap kinerja manajerial. Dari hasil tersebut, maka SAM mampu memediasi pengaruh desentralisasi terhadap kinerja manajerial. Hasil kajian ini menunjukan bahwa semakin besar tingkat pendelegasian wewenang dan tanggung jawab dari manajer puncak kepada manajer tengah kebawah, akan memberikan manfaat bagi manajer tengah kebawah dalam memberikan informasi yang tepat waktu dan akurat tentang aktifitas yang dikerjakan seperti analisis cost dan benefit, atau analisis efisiensi dan efektivitas layanan. Pemanfaatan SAM yang efektif dalam memberikan informasi yang tepat waktu dan akurat tersebut akan meningkatkan kinerja dalam menyelesaikan pekerjaan secara efektif dalam hal menentukan tujuan. Kebijakan dan rencana kegiatan seperti penjadwalan kerja, penyusunan anggaran, dan penyusunan progam kerja serta konsisten dalam pengumpulan dan penyiapan informasi yang biasanya berbentuk catatan dan laporan (Rante et al., 2014).

Hal ini sejalan dengan pendekatan kontijensi bahwa tingkat ketersediaan dari masing-masing karakteristik SAM itu mendukung untuk masing-masing kinerja pada setiap kondisi organisasi. Melalui pendekatan kontijensi ini adanya desentralisasi pada masing-masing organisasi menyebabkan adanya hubungan karakteristik SAM terhadap kinerja manajerial. Menurut Otley (1980) organisasi menghadapi kondisional (kontijensi) agar terbentuk konfigurasi yang sesuai (match) sehingga diharapkan menghasilkan efektifitas organisasi dan kinerja manajerial meningkat.

Hasil tersebut memperluas kajian yang dikemukakan oleh Lempas et al. (2014); Rante et al. (2014), dan Solechan \& Setiawati (2009), yang menyimpulkan bahwa hubungan SAM dan desentralisasi berpengaruh terhadap kinerja manajerial. Berdasarkan logika, teori dan penelitian yang mendukung, maka hipotesis penelitian ini dinyatakan sebagai berikut:

$\mathbf{H}_{4}$ : SAM memediasi pengaruh desentralisasi terhadap kinerja manajerial.

\section{Metoda}

Populasi dalam penelitian ini adalah karyawan pada PT. Perkebunan Nusantara IX Balong Jepara (Persero). Sampel yang digunakan dalam penelitian ini yaitu manajer lini menengah pada PT. Perkebunan Nusantara IX Balong Jepara (Persero). Teknik pengambilan sampel berdasarkan teknik incidental sampling. 
Rumus Slovin digunakan untuk menentukan jumlah sampel yang akan digunakan.

Data primer dan data sekunder dijadikan sumber informasi untuk penelitian ini. Kuesioner yang disebarkepada responden, yaitu para manajer lini menengah pada PT. Perkebunan Nusantara IX Balong Jepara (Persero) merupakan data primer yang dijadikan sumber informasi. Sedangkan data sekunder yaitu berupa data laporan produktivitas lima tahun terakhir yang bersumber dari PT. Perkebunan Nusantara IX Balong Jepara (Persero).

Terdapat empat variabel yang digunakan dalam penelitian ini. Variabel kinerja manajerial di ukur dengan menggunakan instrumen self rating oleh Solechan \& Irawati (2009). Para responden diminta untuk menilai kinerja mereka dibandingkan dengan rata-rata kinerja rekan mereka. Kinerja manajerial ini diukur dengan sembilan item pertanyaan yang diukur dengan lima skala likert. Instrumen ini terdiri dari sembilan kinerja personal yaitu perencanaan, investigasi, koordinasi, evaluasi, pengawasan, staff, negosiasi, perwakilan, dan satu dimensi kinerja secara keseluruhan.

SAM adalah suatu sistem pengolahan informasi keuangan yang digunakan untuk menghasilkan informasi keuangan bagi kepentingan pemakai intern organisasi (Solechan \& Setiawati, 2009). Pengukurannya dengan menggunakan instrumen oleh Solechan \& Irawati (2009), terdiri dari empat dimensi (aspek) yaitu informasi broad scope, timeliness, agregasi, dan integrasi diukur dengan dua item pertanyaan. Masing-masing pertanyaan diukur dalam lima skala likert.

Yukl (2010) mengatakan bahwa kepemimpinan adalah kemampuan individu untuk mempengaruhi, memotivasi, dan membuat orang lain mampu memberikan kontribusinya demi efektivitas dan keberhasilan organisasi. Jadi dapat dikatakan bahwa kepemimpinan merupakan cara mempengaruhi dan memotivasi orang lain agar orang tersebut mau berkontribusi untuk keberhasilan dalam organisasi. Variabel gaya kepemimpinan dalam penelitian ini diukur dengan menggunakan instrumen yang dikembangkan oleh Yukl (2010). Instrumen terdiri dari empat item skala likert dengan empat pertanyaan.

Desentralisasi merupakan pendelegasian wewenang tanggung jawab kepada para manajer lebih rendah. Variabel desentralisasi diukur dengan menggunakan instrumen (Solechan \& Irawati, 2009), yakni diukur dengan lima item pertanyaan dalam lima skala likert. Kelima pertanyaan tersebut untuk mengetahui seberapa jauh pengambilan keputusan didelegasikan pada para manajer, yaitu kebijakan dalam pengambilan produk atau jasa baru, kebijakan 
dalam pemutusan hubungan kerja, penentuan investasi dalam skala besar, pengalokasian anggaran harga jual.

Analisis jalur partial least square (PLS) digunakan sebagai alat pengolahan data. Hubungan kausalitas antar variabel telah dibuat dengan model berdasarkan landasan teoritis. analisa jalur digunakan untuk menentukan pola hubungan antara tiga atau lebih variabel dan tidak dapat digunakan untuk mengkonfirmasi atau menolak hipotesis kausalitas imajiner. PLS digunakan untuk mengetahui kompleksitas hubungan suatu konstruk dan konstruk yang lain, serta hubungan suatu konstruk dan indikator-indikatornya (Yamin \& Kurniawan, 2011).

\section{Hasil dan Pembahasan}

\section{Hasil}

Jumlah populasi dalam penelitian ini adalah sebanyak 136 manajer lini menengah, sehingga presentase kelonggaran yang digunakan adalah $5 \%$ dan hasil perhitungan dapat dibulatkan untuk mencapai kesesuaian. Dari 101 responden, mayoritas responden berjenis kelamin laki-laki sebanyak 74,26\% sisanya sebanyak $25,74 \%$ berjenis kelamin perempuan. Karakteristik dan kondisi kerja di PT. Perkebunan Nusantara IX Balong Jepara (Persero) memerlukan perhatian ekstra yang didukung dengan kemampuan fisik, sehingga laki-laki menjadi dominan. Persentase umur karyawan yang dijadikan responden paling tinggi sebanyak $43,57 \%$ yaitu pada range usia 46-55 tahun, hal ini menunjukkan bahwa pada manajer lini menengah kebawah pada PT. Perkebunan Nusantara IX Balong Jepara (Persero) berada pada usia yang sudah memiliki pengalaman yang tinggi.

Tingkat pendidikan didominasi pada lulusan S1 yaitu sebanyak 80,20\%. Pendidikan akan sangat mempengaruhi kreatifitas dalam melaksanakan pekerjaan yang dibebankan, sehingga dengan dibekali pendidikan yang cukup, maka akan dapat memberikan inovasi dalam bekerja sehingga tujuan perusahaan dapat tercapai. Masa kerja responden terbanyak pada range masa kerja 6-10 tahun sebesar 26,73\% dan sebagian besar kepangkatan responden pada golongan II, yaitu sebanyak 76,24\%.

Uji kecocokan model ditunjukkan pada bagian model fit indices and $P$ values menampilkan hasil tiga indikator fit yaitu average path coefficient (APC), average $R$-square (ARS), dan average variance inflation factor (AVIF). Nilai $\mathrm{P}$ untuk APC dan ARS harus lebih kecil dari 0,05 atau berarti diterima. Selain itu, AVIF sebagai indikator multikolinearitas harus lebih kecil dari 5. Berikut ini adalah hasil output model fit indicesand P values: 
Tabel 1. Hasil Uji Model Fit Indices and P Values

\begin{tabular}{|c|c|c|c|c|}
\hline & Indeks & p-value & Kriteria & Keterangan \\
\hline APC & 0.348 & $P<0.001$ & $P<0,05$ & Diterima \\
\hline ARS & 0.612 & $\mathrm{P}<0.001$ & $P<0,05$ & Diterima \\
\hline \multirow[t]{3}{*}{ AVIF } & 2.428 & & Good If $<5$ & \\
\hline & Good If $<5$ & & & \\
\hline & GK & $\mathrm{D}$ & SAM & KM \\
\hline R-squared coefficients & & & 0.834 & 0.390 \\
\hline Q-squared coefficients & & & 0.834 & 0.383 \\
\hline $\begin{array}{l}\text { Composite reliability } \\
\text { coefficients }\end{array}$ & 0.862 & 0.845 & 0.821 & 0.893 \\
\hline $\begin{array}{l}\text { Cronbach's alpha } \\
\text { coefficients }\end{array}$ & 0.786 & 0.763 & 0.754 & 0.862 \\
\hline
\end{tabular}

Sumber: Data primer diolah

Hasil output di atas, menjelaskan bahwa APC dengan nilai $p$-value $<0,001$ dan ARS dengan $p-$ value $<0,001$. Berdasarkan kriteria, APC dan ARS sudah memenuhikriteria karena memiliki nilai $\mathrm{p}<0,001$. Nilai AVIF $<5$ sudah terpenuhi karena berdasarkan data tersebut AVIF nilainya 2.428. Dengan demikian, maka inner model dapat diterima.

Bisa dilihat dari hasil Uji R-squared coefficients di atas bahwa $R$-squared coefficients lebih besar dari 0 yaitu SAM sebesar 0,834 dan KM sebesar 0,390, hal ini menunjukkan bahwa nilai dari $R$-squared coefficients yaitu model telah fit. Hasil Uji Q-squared coefficients menunjukkan bahwa $Q$-squared lebih besar dari 0 yaitu SAM sebesar 0,834 dan KM sebesar 0,383, hal ini menunjukkan bahwa nilai dari $Q$-squared yaitu model telah fit. Terdapat empat kriteria dalam penggunaan teknik analisa data dengan warp PLS 3.0 untuk menilai outer model yaitu Composite Reliability, Cronbach Alpha, Average Variance Extracted, dan Full Collinearity VIFs yaitu sebagai berikut:

Hasil Uji composite reliability coefficients menyajikan composite reliability coefficients lebih besar dari 0,7 yaitu GK sebesar 0,862, D sebesar 0,845, SAM sebesar 0,821, dan KM sebesar 0,893, hal ini menunjukkan bahwa semua nilai dari Composite reliability coefficients reliabel. Cronbach alpha coefficients yang tersaji dalam hasil uji cronbach's alpha coefficients lebih besar dari 0,7 yaitu GK sebesar 0,786, D sebesar 0,763, SAM sebesar 0,754, dan KM sebesar 0,862, hal ini menunjukkan bahwa semua nilai dari cronbach alpha coefficients yaitu reliabel.

Average variance extracted apat dilihat dalam hasil uji average variances extracted, menunjukkan bahwa average variance extracted lebih besar dari 0,5 yaitu GK sebesar 0,610, D sebesar 0,536, SAM sebesar 0,410, dan KM sebesar 0,513 , hal ini berarti bahwa semua nilai dari average variance extracted yaitu reliabel kecuali nilai dari SAM yaitu cukup reliabel. Kriteria untuk full collinearity VIFs yaitu lebih rendah dari 3,3, sedangkan hasil uji full collinearity 
VIFs di atas menunjukkan GK sebesar 1,392, D sebesar 5196, SAM sebesar 6,588, dan KM sebesar 1,648. Hal ini menunjukkan bahwa GK dan KM reliabel tetapi D dan SAM tidak reliabel.

Berikut ini adalah hasil pengujian analisis jalur dengan menggunakan software warp PLS 3.0 untuk masing-masing variabel:

Tabel 2. Direct dan Indirect effect

\begin{tabular}{|c|c|c|c|c|c|}
\hline \multirow{2}{*}{ No } & \multirow{2}{*}{ Jalur } & \multicolumn{2}{|c|}{ Direct effect } & Indirect effect & Hasil \\
\hline & & Koefesien & P-value & Koefesien & P-value \\
\hline 1 & GK -> KM & -0.025 & 0.425 & & Tidak diterima \\
\hline 2 & $\mathrm{D}->\mathrm{KM}$ & 0.070 & 0.329 & & Tidak diterima \\
\hline 3 & $\begin{array}{l}\text { GK -> SAM -> } \\
\text { KM }\end{array}$ & & & 0.025 & Diterima \\
\hline 4 & $\begin{array}{l}\text { D -> SAM -> } \\
\text { KM }\end{array}$ & & & $<0.001$ & Diterima \\
\hline
\end{tabular}

Sumber: Data primer diolah

Keterangan:

GK : Gaya Kepemimpinan

D : Desentralisasi

SAM : Sistem Akuntansi Manajemen

KM : Kinerja Manajerial

\section{Pembahasan}

\section{Pengaruh Gaya Kepemimpinan Terhadap Kinerja Manajerial}

Hasil penelitian menunjukkan bahwa hipotesis ditolak. Gaya kepemimpinan merupakan pola perilaku yang dimiliki oleh pemimpin selama proses mengarahkan atau membimbing serta mempengaruhi para pekerja. Gaya kepemimpinan dalam perusahaan sebagai faktor yang dominan dalam menentukan dan pembentukan karakter perusahaan. Selanjutnya karakter perusahaan akan mempengaruhi output dari kinerja manajerial. Namun demikian, hasil penelitian ini menunjukkan bahwa gaya kepemimpinan seorang manajer dalam perusahaan tidak berpengaruh terhadap kinerja dari masing-masing anggota organisasi. Artinya perilaku manajer lini di PT. Perkebunan Nusantara IX Balong Jepara tidak direspon oleh karyawannya.

Hasil tersebut memberikan bukti bahwa pada hasil penelitian yang tersaji dalam lampiran, menunjukkan bahwa variabel gaya kepemimpinan atas pernyataan mengenai pimpinan mempengaruhi cara pandang karyawan untuk menyelesaikan masalah pekerjaan sebesar 41 (40,60\%) manajer lini di PT. Perkebunan Nusantara IX Balong Jepara memilih netral. Hal ini tidak sesuai dengan Teori Kontijensi yang menyatakan bahwa kelompok efektif tergantung pada kecocokan antara gaya pemimpin yang berinteraksi dengan 
subordinatnya sehingga situasi menjadi pengendali dan berpengaruh terhadap pemimpin. Para pemimpin mencoba melakukan pengaruhnya kepada anggota kelompok dalam kaitannya dengan situasi-situasi yang spesifik. Berarti manajer lini pada PT. Perkebunan Nusantara IX Balong Jepara memiliki gaya kepemimpinan yang tinggi tetapi tidak berpengaruh terhadap kinerja manajerial, karena tingginya gaya kepemimpinan diukur dari bagaimana karyawan memandang organisasi, mendorong kerja tim, menghargai inovasi, dan meningkatkan prakarsa. Dengan demikian, gaya kepemimpinan yang berorientasi pada kinerja akan menuntut hasil dan harapan yang tinggi dan menekankan pada keagresifan, kompetisi dan pemanfaatan kesempatan, maka dari itu gaya kepemimpinan tidak berpengaruh terhadap kinerja manajerial.

Hasil penelitian ini sejalan dengan Cahyadi \& Handoko (2010); Nurwati et al. (2012); Taruno et al. (2012); Djoemadi \& Noermijati (2014); Widhi \& Setyawati (2015), yang menyatakan bahwa tidak adanya pengaruh interaksi antara gaya kepemimpinan terhadap kinerja manajerial.

\section{Pengaruh Desentralisasi Terhadap Kinerja Manajerial}

Berdasarkan hasil pengolahan data, maka hipotesis kedua dalam penelitian ini tidak dapat diterima. Hal ini disebabkan pada kondisi desentralisasi manajer lebih banyak membutuhkan informasi untuk dapat menjalankan tugasnya secara efisien dan manajer tingkat atas masih memegang peranan penting dalam setiap kegiatannya, agar desentralisasi bisa berpengaruh terhadap kinerja manajerial maka perlu adanya hubungan persial yang terjadi antara desentralisasi dan sistem akuntansi manajemen. Hal ini berhubungan dengan peranan pendelegasian wewenang dan tanggungjawab kepada para manajer. Desentralisasi tidak akan meningkatkan kinerjanya ketika indikator adalah tercapainya efisiensi tidak dilengkapi dengan informasi akuntansi yang memadai.

Hasil penelitian ini sejalan Lempas et al. (2014) serta Solechan \& Setiawati (2009) yang mengemukakan bahwa tidak ditemukan pengaruh signifikan hubungan antara desentralisasi dan kinerja manajerial, diduga adanya pengaruh lain yang lebih dominan untuk berpartisipasi.

\section{SAM Memediasi Pengaruh Gaya Kepemimpinan Terhadap Kinerja Manajerial}

Sesuai dengan hasil pengolahan data, hipotesis ketiga dalam penelitian ini diterima. Hal ini sesuai dengan teori kontijensi yang menyatakan bahwa SAM dan gaya kepemimpinan merupakan faktor kondisional yang akan mengalami penyesuaian sehubungan dengan kondisi situasional yang terjadi dalam perusahaan yang menyebabkan perbedaan kebutuhan informasi.Penelitian ini 
sejalandengan penelitian Rante et al. (2014) dan Yuliana (2010) yang menyimpulkan bahwa kombinasi derajat managerial style dengan lingkup SAM yang tinggi akan mempunyai pengaruh yang positif terhadap kinerja manajerial.

\section{SAM Memediassi Pengaruh Desentralisasi Terhadap Kinerja Manajerial}

Keputusan hasil pengolahan data membuktikan bahwa hipotesis keempat dalam penelitian ini diterima. Hal ini sejalan dengan pendekatan kontijensi bahwa tingkat ketersediaan dari masing-masing karakteristik SAM mendukung untuk masing-masing kinerja pada setiap kondisi organisasi. Melalui pendekatan kontijensi ini desentralisasi pada masing-masing organisasi menyebabkan adanya hubungan karakteristik SAM terhadap kinerja manajerial. SAM memegang peranan penting dalam sistem pengendalian manajemen sebuah organisasi, terutama dalam proses perencanaan dan pengendalian dalam suatu organisasi. Oleh karenanya, manajemen menerapkan SAM secara tepat mengingat tugas-tugas perusahaan semakin kompleks sehingga dapat membantu meringankan kinerja perusahaan. Hasil tersebut memperluas kajian yang dikemukakan oleh Lempas et al. (2014) serta Rante et al. (2014) yang menyimpulkan bahwa SAM dapat digunakan untuk meningkatkan hubungan antara desentralisasi terhadap kinerja manajerial.

Berikut ini merupakan gambar hasil penelitian dari effect size yang telah diperoleh berdasarkan pengolahan data:

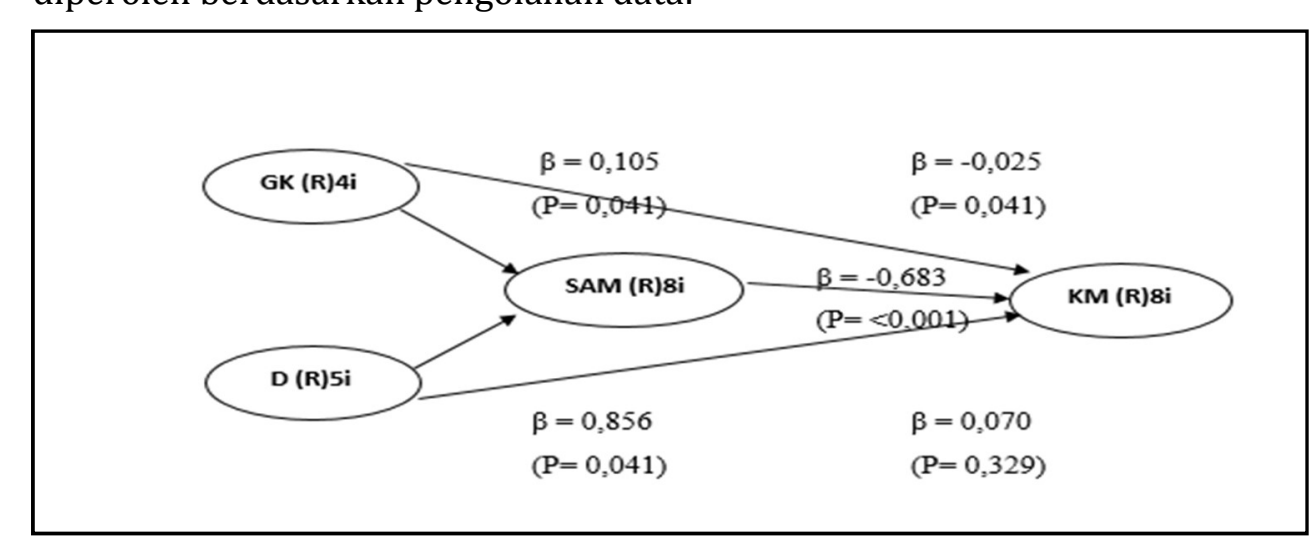

Gambar 1. Effect Size

Keterangan:

GK : gaya kepemimpinan

D : desentralisasi

SAM : sistem akuntansi manajemen

KM : kinerja manajerial 


\section{Simpulan}

Berdasarkan analisis dan pembahasan pada bagian sebelumnya, maka dapat ditarik kesimpulan sebagai berikut: (1) gaya kepemimpinan tidak berpengaruh terhadap kinerja manajerial pada PT. Perkebunan Nusantara IX Balong Jepara (Persero); (2) desentralisasi tidak berpengaruh terhadap kinerja manajerial pada PT. Perkebunan Nusantara IX Balong Jepara (persero); (3) SAM memediasi pengaruh gaya kepemimpinan terhadap kinerja manajerial pada PT. Perkebunan Nusantara IX Balong Jepara (Persero); (4) SAM memediasi pengaruh desentralisasiterhadap kinerja manajerial pada PT. Perkebunan Nusantara IX Balong Jepara (Persero).

Dalam penelitian ini terdapat beberapa keterbatasan, antara lain: (1) instrumen dalam penelitian ini dinilai dengan menggunakan self rating, sehingga hasilnya dapat tidak objektif; (2) variabel independen yang dipilih tidak dapat mempengaruhi variabel dependen. Dengan keterbatasan dalam penelitian ini, maka saran untuk penelitan selanjutnya adalah: (1) menggunakan instrument penilaian yang lain selain self rating seperti score; (2) untuk penelitian selanjutnya perlu menambah variabel independen lainnya untuk melihat pengaruh terhadap variabel dependen, seperti motivasi kerja, budaya organisasi, dan lain-lain, karena berdasarkan hasil penelitian sebelumnya variabel-variabel ini digunakan untuk menguji pengaruh terhadap variabel dependen.

\section{Daftar Pustaka}

Cahyadi \& Handoko. (2010). Pengaruh komitmen organisasi, gaya kepemimpinan, dan ketidakpastian lingkungan terhadap hubungan partisipasi anggaran dengan kinerja manajerial. Jurnal Akuntansi Kontemporer, Vol. 2, No. 2, Hal 171-189.

Cahyaningrum, Y.S., \& Suprapti, S. (2016). Pengaruh karakteristik informasi akuntansi dan desentralisasi terhadap kinerja manajerial. Jurnal Ilmiah UNTAG Semarang, Vol. 5, No, 2, Hal. 83-99.

Djoemadi, Farid Rokhman \& Noermijati. (2014). Pengaruh Karakteristik Pemimpin dan Penghargaan terhadap Motivasi Kerja dan Kinerja Karyawan (Studi pada PT. Visi Karya Agritama).Jurnal Aplikasi Manajemen. Vol. 12, No.2 Juni 2014, ISSN: 1693-5241.

Elenkov \& Detelin, S. (2002). Effects of leadership on organizational performance in Russian companies, Journal of Business Research. 55. 467-480.

Yukl, Gary, (2010), Kepemimpinan dalam Organisasi, Edisi Kelima. Jakarta: PT. Indeks.

Gordon, L. A \& Miller D. (1976). A Contingency Framework for the Design of Accounting Information Systems. Accounting, Organizations and Society, Vol.1, No. 1, pp. 59-69.

Lempas, Y., Ilat, V., \& Sabijono, H. (2014). Desentralisasi dan Sitem Akuntansi Manajemen terhadap Kinerja Manajerial. Jurnal Riset Ekonomi, Manajemen, Bisnis dan Akuntansi,Vol. 2, No.1, pp. 431-440

Namawi, Hadari. (2005). Manajemen Sumber Daya Manusia untuk Bisnis yang Kompetitif. Gajah Mada University-Press, Yogyakarta. 
Nurwati, N.U., Margono, S., \& Surachman. (2012). Pengaruh Kepemimpinan terhadap Budaya Organisasi, Komitmen Kerja, Perilaku Kerja, Kinerja Pegawai (studi pada SKPD Provinsi Sulawesi Tenggara). Jurnal Aplikasi Manajemen, Vol. 10, No. 01, Maret.

Ogbonna \& Harris, Lloyd, C. (2000). Leadership Style, Organizational Culture and Performance: Empirical Evidence From UK Companies. International Journalof Human Resource Management, 11:4 August, p.766-788.

Otley, D.T. (1980). The Contingency Theory of Management Accounting: Achievement and Prognosis. Accounting, Organizations and Society, Vol.5, No.04,pp. 413428.

Rante, A., Rosidi, \& Ali, D. (2014). Sistem Akuntansi Manajemen sebagai Pemediasi Pengaruh Gaya Kepemimpinan dan Desentralisasi terhadap Kinerja Manajerial. Jurnal Aplikasi Manajemen, Vol. 12, No. 3.

Robbins, Stephen P. \& Coulter, Mary. (2007). Manajemen Edisi Kesepuluh. Jakarta: Penerbit Erlangga

Rowold, J. (2011). Relationship between leadership behaviors and performance: The moderating role of a workteam's level of age, gender, and cultural heterogeneity. Leadership \& Organization Development Journal, Vol.32 Iss: 6 pp. 628-647.

Sari, Jas Oktavia. (2016). Pengaruh Partisipasi Penyusunan Anggaran, Akuntabilitas Publik, Desentralisasi, dan Sistem Pengendalian Intern terhadap Kinerja Manajerial Pemerintah Daerah. Jurnal Aplikasi Mnajemen, Vol. 3, No. 1.

Simon. (1987). Sistem Pakar Teori dan Aplikasi. Andi Yogyakarta: Yogyakarta

Solechan \& Setiawati. (2009). Pengaruh Karakteristik Sistem Akuntansi Manajemen dan Desentralisasi Sebagai Variabel Moderating Terhadap Kinerja Manajerial (studi empiris perusahaan manufaktur di kabupaten semarang). Fokus Ekonomi, Vol. 4, No. 1.

Suryo, B. (2008). Pengaruh Gaya Kepemimpinan Transformasional, Budaya Organisasi dan Inovasi Terhadap Kinerja Pengelola Panti Asuhan di Kota Tomohon dan Kabupaten Minahasa. Jurnal Aplikasi Manajemen. Vol. 8, No. 2.

Taruno, F. X,. Soewarto Citro, Armanu Thoyib, Djumilah Zain \& Mintarti Rahayu (2012). Pengaruh Gaya Kepemimpinan terhadap Kinerja Dosen dengan Kepuasan Kerja dan motivasi kerja sebagai Mediator (Studi pada Perguruan Tinggi Swastadi Jayapura). Jurnal Aplikasi Manajemen. Vol. 10, No. 3, Hal. 495-509.

Tucunan, A., Supartha, G., \& Riana, G. (2014). Pengaruh Kepemimpinan Transformasional Terhadap Motivasi Dan Kinerja Karyawan. E-Jurnal Ekonomi dan Bisnis Universitas Udaya, Vol. 3, No. 9.

Widhi, N., \& Setyawati, E. (2015). Pengaruh Independensi, Gaya Kepemimpinan, Komitmen Organisasi dan Pemahaman Good Governance terhadap Kinerja Auditor Pemerintah. Jurnal Manajemen dan Bisnis, Vol. 19, No. 1.

Yamin, Sofyan \& Heri Kurniawan. (2011). Partial Least Square Path Modeling. Salemba Infotek

Yuliana, C. (2010, 13-14 Oktober). Peran Kepemimpinan dalam Pencapaian Kinerja Organisasi Melalui Budaya, Strategi, dan Sistem Akuntansi Manajemen Organisasi.Paper dipresentasikan pada acara Simposium Nasional Akuntansi $X I I I$, Purwokerto. 


\section{Lampiran}

\section{Lampiran 1. Deskripsi Variabel Penelitian}

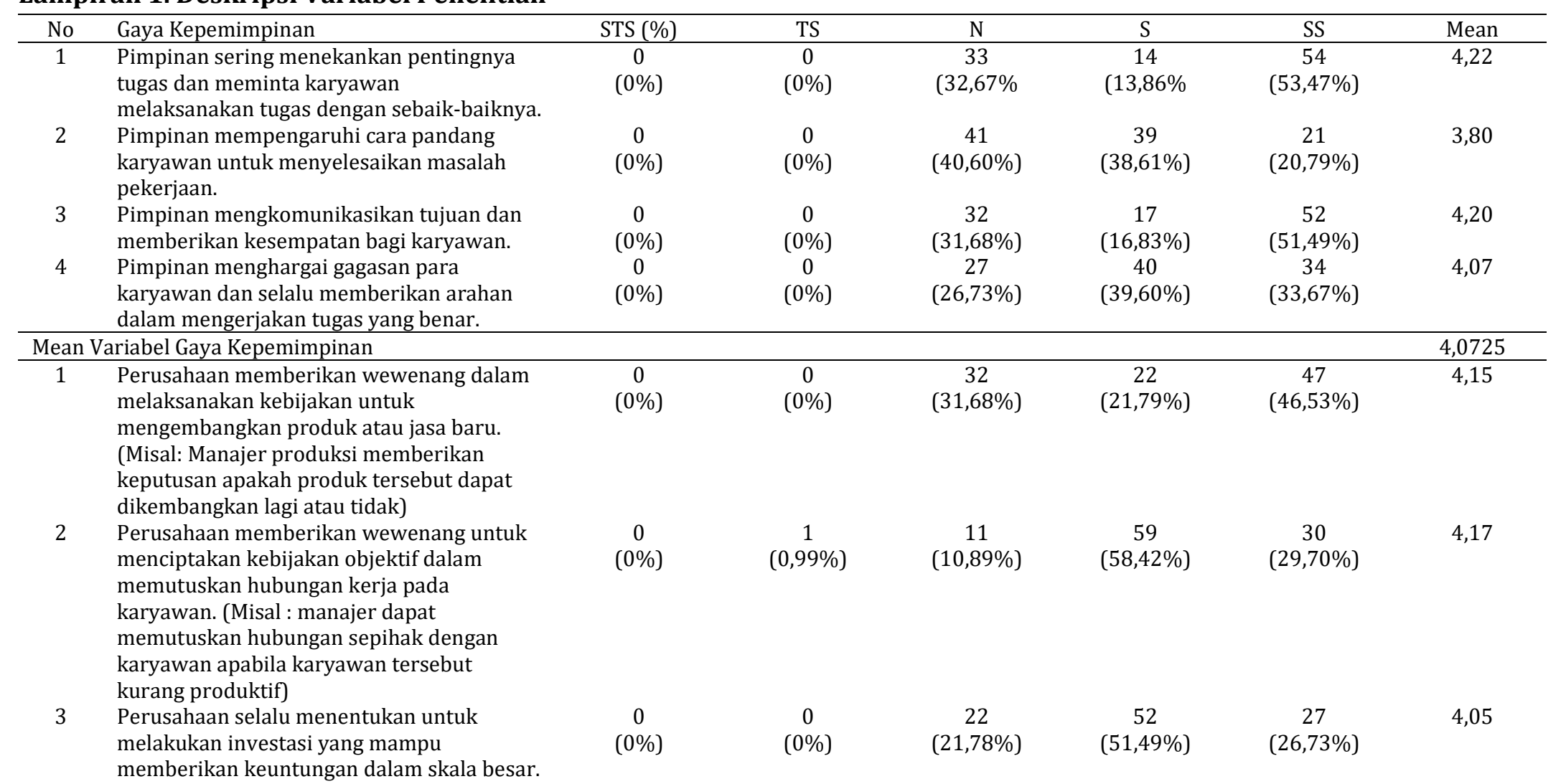




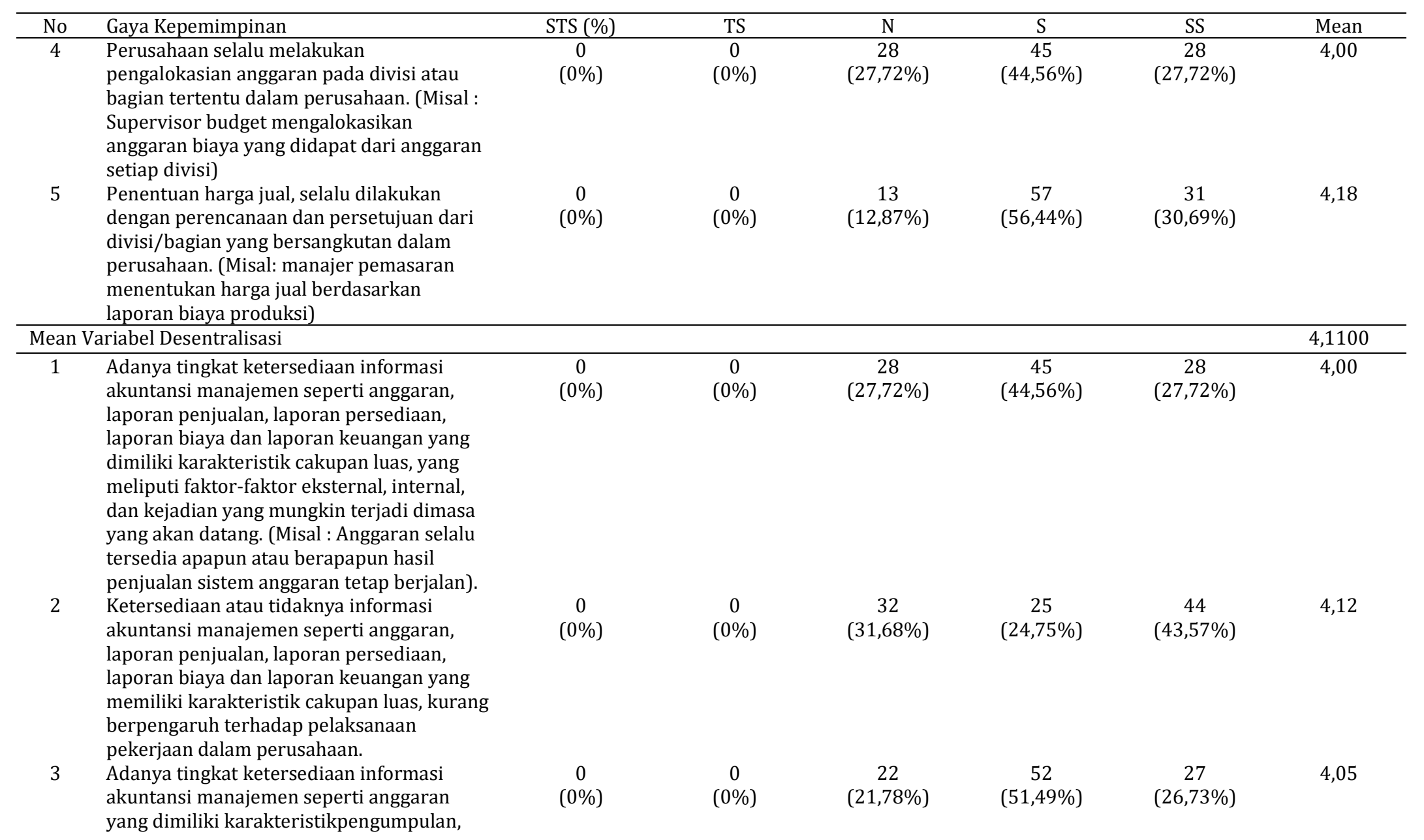




\begin{tabular}{|c|c|c|c|c|c|c|c|}
\hline No & Gaya Kepemimpinan & STS (\%) & TS & $\mathrm{N}$ & $S$ & SS & Mean \\
\hline & $\begin{array}{l}\text { yaitu mengenai kelengkapan informasi } \\
\text { agregrasi. (Misal: anggaran biaya produksi } \\
\text { disajikan secara lengkap dan ringkas). }\end{array}$ & & & & & & \\
\hline 4 & $\begin{array}{l}\text { Ketersediaan atau tidaknya informasi } \\
\text { akuntansi manajemen seperti anggaranyang } \\
\text { memiliki karakteristikpengumpulan, kurang } \\
\text { berpengaruh terhadap pelaksanaan } \\
\text { pekerjaan dalam perusahaan. }\end{array}$ & $\begin{array}{c}0 \\
(0 \%)\end{array}$ & $\begin{array}{c}0 \\
(0 \%)\end{array}$ & $\begin{array}{c}41 \\
(40,60 \%)\end{array}$ & $\begin{array}{c}29 \\
(28,71 \%)\end{array}$ & $\begin{array}{c}31 \\
(30,69 \%)\end{array}$ & 3,90 \\
\hline 5 & $\begin{array}{l}\text { Adanya tingkat ketersediaan informasi } \\
\text { akuntansi manajemen yang dimiliki } \\
\text { karakteristik informasiintegrasi, yaitu } \\
\text { mengenai kompleksitas, } \\
\text { kelengkapan(detail), serta infomasi antar } \\
\text { unit/bagian. (Misal : anggaran biaya bahan } \\
\text { baku dipakai oleh bagian produksi, } \\
\text { kemudian bagian produksi melaporkan ke } \\
\text { bagian keuangan). }\end{array}$ & $\begin{array}{c}0 \\
(0 \%)\end{array}$ & $\begin{array}{c}0 \\
(0 \%)\end{array}$ & $\begin{array}{c}28 \\
(27,72 \%)\end{array}$ & $\begin{array}{c}22 \\
(21,78 \%)\end{array}$ & $\begin{array}{c}51 \\
(50,50 \%)\end{array}$ & 4,23 \\
\hline 6 & $\begin{array}{l}\text { Ketersediaan atau tidaknya informasi } \\
\text { akuntansi manajemen seperti anggaran } \\
\text { yang memiliki karakteristikintegrasi, } \\
\text { kurang berpengaruh terhadap pelaksanaan } \\
\text { pekerjaan dalam perusahaan. }\end{array}$ & $\begin{array}{c}0 \\
(0 \%)\end{array}$ & $\begin{array}{c}0 \\
(0 \%)\end{array}$ & $\begin{array}{c}27 \\
(26,73 \%)\end{array}$ & $\begin{array}{c}63 \\
(63,38 \%)\end{array}$ & $\begin{array}{c}11 \\
(10,89 \%)\end{array}$ & 3,84 \\
\hline 7 & $\begin{array}{l}\text { Adanya tingkat ketersediaan informasi } \\
\text { akuntansi manajemenseperti anggaran yang } \\
\text { dimiliki karakteristik informasi ketepatan } \\
\text { waktu, yaitu mengenai informasi terkini, } \\
\text { interval waktu antar kebutuhan informasi } \\
\text { dan ketersediaan informasi.(Misal : } \\
\text { ketepatan waktu bagian produksi } \\
\text { membutuhkan informasi persediaan bahan } \\
\text { baku agar pelaksaan produksi berjalan } \\
\text { sesuai dengan kinerja produksi) }\end{array}$ & $\begin{array}{c}0 \\
(0 \%)\end{array}$ & $\begin{array}{c}0 \\
(0 \%)\end{array}$ & $\begin{array}{c}21 \\
(20,79 \%)\end{array}$ & $\begin{array}{c}64 \\
(63,37 \%)\end{array}$ & $\begin{array}{c}16 \\
(15,84 \%)\end{array}$ & 3,95 \\
\hline
\end{tabular}




\begin{tabular}{|c|c|c|c|c|c|c|c|}
\hline No & Gaya Kepemimpinan & STS (\%) & TS & $\mathrm{N}$ & $\mathrm{S}$ & SS & Mean \\
\hline 8 & $\begin{array}{l}\text { Ketersediaan atau tidaknya informasi yang } \\
\text { memiliki karakteristik informasi ketepatan } \\
\text { waktu, tidak berpengaruh terhadap } \\
\text { pelaksanaan pekerjaan dalam perusahaan. }\end{array}$ & $\begin{array}{c}0 \\
(0 \%)\end{array}$ & $\begin{array}{c}0 \\
(0 \%)\end{array}$ & $\begin{array}{c}29 \\
(28,71 \%)\end{array}$ & $\begin{array}{c}31 \\
(30,69 \%)\end{array}$ & $\begin{array}{c}41 \\
(40,60 \%)\end{array}$ & 4,12 \\
\hline \multicolumn{7}{|c|}{ Mean Variabel Sistem Akuntansi Manajemen } & 4,0263 \\
\hline 1 & $\begin{array}{l}\text { Perencanaan } \\
\text { Menentukan tujuan, sasaran, kebijakan, dan } \\
\text { tindakan atau pelaksanaan penjadwalan } \\
\text { kerja, penganggaran, merancang prosedur, } \\
\text { pemrograman. (Misal : merencanakan } \\
\text { anggaran biaya produksi sesuai dengan } \\
\text { permintaan dari pemesan). }\end{array}$ & $\begin{array}{c}0 \\
(0 \%)\end{array}$ & $\begin{array}{c}0 \\
(0 \%)\end{array}$ & $\begin{array}{c}15 \\
(14,85 \%)\end{array}$ & $\begin{array}{c}64 \\
(63,37 \%)\end{array}$ & $\begin{array}{c}22 \\
(21,78 \%)\end{array}$ & 4,61 \\
\hline 2 & $\begin{array}{l}\text { Perencanaan } \\
\text { Menentukan tujuan, sasaran, kebijakan, dan } \\
\text { tindakan atau pelaksanaan penjadwalan } \\
\text { kerja, penganggaran, merancang prosedur, } \\
\text { pemrograman. (Misal : merencanakan } \\
\text { anggaran biaya produksi sesuai dengan } \\
\text { permintaan dari pemesan). }\end{array}$ & $\begin{array}{c}0 \\
(0 \%)\end{array}$ & $\begin{array}{c}0 \\
(0 \%)\end{array}$ & $\begin{array}{c}27 \\
(26,73 \%)\end{array}$ & $\begin{array}{c}31 \\
(30,69 \%)\end{array}$ & $\begin{array}{c}43 \\
(42,58 \%)\end{array}$ & 4,16 \\
\hline 3 & $\begin{array}{l}\text { Perencanaan } \\
\text { Menentukan tujuan, sasaran, kebijakan, dan } \\
\text { tindakan atau pelaksanaan penjadwalan } \\
\text { kerja, penganggaran, merancang prosedur, } \\
\text { pemrograman. (Misal : merencanakan } \\
\text { anggaran biaya produksi sesuai dengan } \\
\text { permintaan dari pemesan). }\end{array}$ & $\begin{array}{c}0 \\
(0 \%)\end{array}$ & $\begin{array}{c}0 \\
(0 \%)\end{array}$ & $\begin{array}{c}31 \\
(30,69 \%)\end{array}$ & $\begin{array}{c}57 \\
(56,44 \%)\end{array}$ & $\begin{array}{c}13 \\
(12,87 \%)\end{array}$ & 3,95 \\
\hline 4 & $\begin{array}{l}\text { Perencanaan } \\
\text { Menentukan tujuan, sasaran, kebijakan, dan } \\
\text { tindakan atau pelaksanaan penjadwalan } \\
\text { kerja, penganggaran, merancang prosedur, } \\
\text { pemrograman. (Misal : merencanakan } \\
\text { anggaran biaya produksi sesuai dengan } \\
\text { permintaan dari pemesan). }\end{array}$ & $\begin{array}{c}0 \\
(0 \%)\end{array}$ & $\begin{array}{c}0 \\
(0 \%)\end{array}$ & $\begin{array}{c}22 \\
(21,78 \%)\end{array}$ & $\begin{array}{c}61 \\
(60,40 \%)\end{array}$ & $\begin{array}{c}18 \\
(17,82 \%)\end{array}$ & 3,96 \\
\hline
\end{tabular}




\begin{tabular}{|c|c|c|c|c|c|c|c|}
\hline No & Gaya Kepemimpinan & STS (\%) & $\mathrm{TS}$ & $\mathrm{N}$ & $S$ & SS & Mean \\
\hline 5 & $\begin{array}{l}\text { Mengawasi (supervisi) } \\
\text { Bapak / Ibu mengarahkan, memimpin, } \\
\text { mengembangkan, membimbing, melatih } \\
\text { dan menjelaskan peraturan kerja pada } \\
\text { bawahan, memberi tugas pekerjaan dan } \\
\text { menangani keluhan. (Misal : pimpinan } \\
\text { mengadakan metting bulanan untuk } \\
\text { mengembangkan kinerja karyawan). }\end{array}$ & $\begin{array}{c}0 \\
(0 \%)\end{array}$ & $\begin{array}{c}0 \\
(0 \%)\end{array}$ & $\begin{array}{c}44 \\
(43,56 \%)\end{array}$ & $\begin{array}{c}41 \\
(40,60 \%)\end{array}$ & $\begin{array}{c}16 \\
(15,84 \%)\end{array}$ & 3,72 \\
\hline 6 & $\begin{array}{l}\text { Pemilihan staf } \\
\text { Mempertahankan angkatan kerja di bagian } \\
\text { Bapak / Ibu merekrut, mewawancarai dan } \\
\text { memilih pegawai baru, mempromosikan } \\
\text { dan memutasi pegawai. }\end{array}$ & $\begin{array}{c}0 \\
(0 \%)\end{array}$ & $\begin{array}{c}0 \\
(0 \%)\end{array}$ & $\begin{array}{c}23 \\
(22,77 \%)\end{array}$ & $\begin{array}{c}49 \\
(48,52 \%)\end{array}$ & $\begin{array}{c}29 \\
(28,71 \%)\end{array}$ & 4,06 \\
\hline 7 & $\begin{array}{l}\text { Negosiasi } \\
\text { Pembelian, penjualan atau melakukan } \\
\text { kontrak untuk barang dan jasa, } \\
\text { menghubungi pemasok, tawar-menawar } \\
\text { dengan wakil penjual, tawar-menawar } \\
\text { secara kelompok. (Misal : melakukan tawar- } \\
\text { menawar persetujuan kontrak kerjasama } \\
\text { dengan klien) }\end{array}$ & $\begin{array}{c}0 \\
(0 \%)\end{array}$ & $\begin{array}{c}0 \\
(0 \%)\end{array}$ & $\begin{array}{c}39 \\
(38,62 \%)\end{array}$ & $\begin{array}{c}36 \\
(35,64 \%)\end{array}$ & $\begin{array}{c}26 \\
(25,74 \%)\end{array}$ & 3,87 \\
\hline 8 & $\begin{array}{l}\text { Perwakilan } \\
\text { Menghadiri pertemuan-pertemuan dengan } \\
\text { kantor pusat, pertemuan dengan pimpinan } \\
\text { pusat, mempromosikan tujuan umum } \\
\text { perusahaan Bapak / Ibu. (Misal : Manager } \\
\text { mewakili perusahaan dalam perkumpulan } \\
\text { perusahaan di seluruh Indonesia) }\end{array}$ & $\begin{array}{c}0 \\
(0 \%)\end{array}$ & $\begin{array}{c}0 \\
(0 \%)\end{array}$ & $\begin{array}{c}33 \\
(32,67 \%)\end{array}$ & $\begin{array}{c}45 \\
(44,56 \%)\end{array}$ & $\begin{array}{c}23 \\
(22,77 \%)\end{array}$ & 3,90 \\
\hline Mean & ariabel Kinerja Manajerial & & & & & & 4,0288 \\
\hline
\end{tabular}

